\title{
The Influence of Leadership Style, Motivation, and Training on Teachers' Performance at Junior High School of Gandus Palembang South Sumatera
}

\author{
Yuli Samsiyah $^{1 *}$, Syarwani Ahmad ${ }^{2}$, Mulyadi $^{2}$ \\ ${ }^{I}$ SMP Negeri 39 Gandus Palembang \\ ${ }^{2}$ Universitas PGRI Palembang \\ *Corresponding author Email: yulisamsiyah146@gmail.com
}

\begin{abstract}
This research aimed to analyze the influence of leadership style, motivation, and training on teachers' performance at the Junior High School of Gandus Palembang, South-Sumatera. This research used a quantitative method with an inferential correlation technique. The population in this research was all teachers at SMP Gandus, Palembang, South Sumatera Indonesia with a sample using 97 teachers. The data were collected through questionnaires, documentation, and interview. The results showed that there were a simultaneous and positive influence between leadership style, motivation, and training on teacher performance with an F-count of 1366.03 which was greater than the F-table value of 2.70, and the R Square value of 0.978. This shows that the magnitude of the influence of leadership style, motivation, and training on teacher performance is $97.8 \%$, while the remaining $2.2 \%$ is determined by other variables. Leadership style, motivation, and training are important factors in improving a teacher's performance.
\end{abstract}

Keywords: Leadership Style, Motivation, Training, Teacher Performance.

\section{INTRODUCTION}

Education is a major part of the process of developing Human Resources (HR) to create and strengthen the economic growth of a country, therefore the sustainable development of teacher educators must be done to improve the quality of education. The role of schools as educational institutions, in this case, is very important in producing highly qualified and competent human resources [1].

Various factors can influence the success of schools in creating quality human resources, one of which is the role of the principal as a manager in improving administrative tasks to achieve educational goals in schools for which he is responsible. The leadership of the principal must be able to strive to improve teacher performance through the education staff capacity building program, therefore the personality, ability, and skills to lead an educational institution must be owned by the principal [2].

The leadership style is one of the key aspects of the principal in living an organizational life because the leadership style can harmonize the process of cooperation between people in an organization so that the principal can direct, influence, and move a person or group to achieve certain goals in certain situations. This process can of course run well if a teacher also has good motivation in carrying out his duties [3].

Motivation can support human behavior so that they are willing to work harder to achieve optimal results. The motivation of a teacher plays an important role in determining the success of the teaching and learning process. In the process, teachers have different characteristics and behaviors, some are passionate and full of responsibility, some are doing work without being based on a sense of responsibility. This condition is a problem in almost all formal educational institutions [4].

The role and strategic position of a teacher with current developments and technology require a teacher to always develop his / her abilities to become a qualified and professional teacher. This self-development can be done through training, training is an activity that has the aim of improving and developing attitudes, behavior and skills, and knowledge of employees according to the wishes of the organization [5]. Of course, some of these things can be an important part of influencing a teacher's performance. 
The interviews with principals at SMP Negeri all Gandus Palembang District are generally good, but there are still some teachers whose performance is not good enough, this can be influenced by fluctuating motivation, teachers have high morale only if there is an increased rank or there are other incentives. Even though efforts have been made for all teachers to attend training, it is still not optimal. Based on this phenomenon, researchers are interested in knowing more about the leadership style, motivation, and training of teacher performance.

\section{METHODS}

This is a quantitative research with analytic descriptive design and correlational inferential techniques. The variables in this study consisted of 3 (three) independent variables, namely; leadership style $\left(\mathrm{X}_{1}\right)$, motivation $\left(\mathrm{X}_{2}\right)$ and training $\left(\mathrm{X}_{3}\right)$, and 1 (one) dependent variable, namely teacher performance $(\mathrm{Y})$.

All junior high school teachers in Gandus South Sumatra as the population in this study with the sampling technique of porpotinoned stratified random sampling totaling 97 teachers. The sample in this study were teachers who taught at Gandus Palembang State Junior High School and were actively working, not on leave.

The instrument for measuring leadership style uses a leadership style questionnaire with 28 statement items. This questionnaire has been tested for validity and reliability with Cronbach's alpha 0.968. The instrument for measuring motivation uses a motivation questionnaire with 25 statement items. This questionnaire has been tested for validity and reliability with Cronbach's alpha 0.964. The instrument for measuring training used a training questionnaire with 23 statement items. This questionnaire has been tested for validity and reliability with Cronbach's alpha 0.984 . The instrument for measuring teacher performance uses a performance questionnaire with 25 statement items. This questionnaire has been tested for validity and reliability with Cronbach's alpha 0.981. All instruments in this study used a Likert scale, and the data collection process was carried out for 3 months, starting from OctoberDecember 2020. Data analysis in this study using SPSS version 25. The analysis used is a linear regression model.

\section{RESULTS AND DISCUSSION}

Table 1 and 2 are description of characteristics of respondent and t-test result. Based on table 1, it is known that for gender, the most female teachers amounted to 55 people $(56.70 \%)$, and for the education category at most had an S1 education level, namely 61 people $(62.88 \%)$.
Table 1. Respondent Characteristics

\begin{tabular}{llc} 
Characteristics & N & Percentage (\%) \\
\hline Gender & & \\
Man & 42 & 43.29 \\
Woman & 55 & 56.70 \\
\hline Education & & \\
Master Degree & 36 & 37.11 \\
Bahelor Degree & 61 & 62.88 \\
\hline
\end{tabular}

Table 2. T-Test Result

\begin{tabular}{lc}
\hline \multicolumn{1}{c}{ Variable } & T-Test \\
\hline Leadership Style & 16.140 \\
\hline Motivation & 4.791 \\
\hline Training & 2.686 \\
\hline
\end{tabular}

Table 2 shows that the results of t-arithmetic for Leadership Style are 16,140, motivation 4,791, and training is 2,686. whereas from the t-table by taking a significant level $(\alpha) 5 \%$ and $\mathrm{df}=\mathrm{n}-\mathrm{k}-1=97-3-1=93$ the two-sided test is obtained t-table is 1.66140 .

Table 3. Multivariate-Test Result (ANOVA)

\begin{tabular}{lcccc}
\hline Model & Df & $\begin{array}{c}\text { Mean } \\
\text { Square }\end{array}$ & F & Sig. \\
\hline $\begin{array}{l}\text { Regres } \\
\text { Sion }\end{array}$ & 3 & 10266.497 & 1366.03 & $.000^{\mathrm{a}}$ \\
\hline $\begin{array}{l}\text { Residu } \\
\text { al }\end{array}$ & 93 & 7.516 & & \\
\hline Total & 96 & & & \\
\hline
\end{tabular}

Table 3. obtained the F-count coefficient of 1366.03 which is greater than the F-table value of 2.70 , means $\mathrm{F}_{\text {count }}>\mathrm{F}_{\text {table }}$, so it can be concluded that leadership style, motivation, and training have a simultaneous effect on the performance of teachers at Gandus Palembang Junior High School.

Table 4. Coefficient of Ditermination

\begin{tabular}{ccccc} 
Model & $\mathbf{R}$ & $\begin{array}{c}\mathbf{R} \\
\text { Square }\end{array}$ & $\begin{array}{c}\text { Adjusted } \\
\mathbf{R} \\
\text { Square }\end{array}$ & $\begin{array}{c}\text { Std. } \\
\text { Error }\end{array}$ \\
\hline $\mathbf{1}$ & $.989^{\mathrm{a}}$ & .978 & .977 & 2.74145 \\
\hline
\end{tabular}

Table 4 proved the Adjusted R Square value of 0.978 , it can be seen that the contribution or magnitude of the influence of the independent variables, namely leadership style, motivation, and training on the dependent variable, namely teacher performance is $97.8 \%$ while the remaining $2.2 \%$ is determined by other variables.

\section{Leadership and Teacher Performance}

Based on the results of data analysis, it was found that the principal's leadership style had a positive and 
significant effect on teacher performance at SMP Negeri Gandus Palembang. The results of this study are also in accordance with research [6] [7], that there is a significant effect of leadership style on teacher performance. This is also in line with the opinion [8], that leadership can have an impact directly, or indirectly. The direct impact is, for example, by providing incentives, giving inspirational lectures on the importance of work or other matters related to the profession as a teacher, while indirectly, for example, changing the organizational culture to become quality and increasing loyalty to the organization. The results of this study also support the results of research [9], that the principal's leadership has a significant effect on teacher performance. This is because the principal is a figure who becomes a role model and role model for teachers, especially in carrying out the teaching and learning process. According to [10], also said that the principal is one of the components of education that has the most role in improving the quality of education.

\section{Motivation and Teacher Performance}

Based on the results of data analysis, it was found that motivation had a positive and significant effect on teacher performance at SMP Negeri Gandus Palembang. The results of this study also support the results of research [11] [12] [13], that there is a significant effect of work motivation on teacher performance. This indicates that a teacher's work activities can be influenced by work motivation to achieve maximum performance. According to [14], motivation is an impulse that arises in a person who moves him to do something. Teachers who have high work motivation will always work hard to overcome all kinds of problems faced in the hope of achieving better results. Likewise expressed by [15], a person's motivation can arise from within the individual, because of the attraction to the object, as well as from outside, due to encouragement from other subjects or demands for self-status improvement. Both the motivation that comes from within and from outside, as much as possible are used by the teacher to increase his morale so that it can influence the quality of work results.

\section{Training and Teacher Performance}

Based on the results of data analysis, it was found that training had a positive and significant effect on teacher performance at SMP Negeri Gandus Palembang. This is in line with research conducted by [5] [16], the result is that training has a significant influence on teacher performance and implies that the more often teachers attend relevant training, the better the teacher's performance will be. Based on these results, it can be argued that training is a necessity that a teacher must often follow in carrying out his duties to improve his performance in teaching. This is also in line with the opinion [10], stating that teachers who have high performance will be passionate and try to improve their competence, both concerning planning, implementing, and assessing learning so that optimal work results are obtained. Likewise the opinion [17], in his research, revealed that teachers who attended training in both the knowledge and skills categories had a significant change for the better for improving teacher quality and performance.

\section{Leadership Style, Motivation, Training, and Teacher Performance}

Based on the results of the analysis that the leadership style, motivation, and training simultaneously influence the performance of the SMP Negeri Gandus Palembang District. The results of this study are consistent with research conducted by [18] [19], leadership style and motivation have a significant effect on teacher performance. The leadership style can be the direction and influence the activities or interests of others at work, and with the creation of motivation in someone, it will certainly greatly affect the performance of a teacher. This is also supported by research conducted [20] [21]], that motivation and training have a significant effect on teacher performance. The positive effect of the teacher following the training will make the teacher open and trained, both in knowledge, skills, and mindset, as well as a disciplined attitude to work which of course will also encourage teachers to be motivated to implement it into the teaching and learning process in the classroom. The result will certainly improve the performance of a teacher to become a qualified and professional teacher.

\section{CONCLUSION}

Based on the results of the analysis, it shows that leadership style, motivation, and training have a very simultaneous influence on teacher performance at Gandus Palembang. It is hoped that the principal can have a role through his leadership style to be able to motivate, and encourage, to attend teacher training, so that ultimately it can improve the performance of a teacher.

\section{REFERENCES}

[1] Fitria. (2020). Peran Kepala Sekolah Dalam Upaya Meningkatkan Kinerja Staff Tata Usaha di Sekolah Dasar, Pascasarjana Universitas PGRI Palembang.

[2] Supatmi, M. Suib, \& M. Sukri. (2014). Peranan Kepala Sekolah Sebagai Manajer Dalam Meningkatkan Tugas Tata Usaha di SMPN 1 Singkawang. Jurnal Pendidik. dan Pembelajaran Khatulistiwa, vol. 3, no. 4, 2014. https://jurnal.untan.ac.id/index.php/jpdpb/article/vi ew/5442 
[3] Arismunandar. (2007). Pendekatan Sistem dalam Pengembangan Sekolah. Jurnal Tenaga Kependidikan, vol. 1, no. 1. https://media.neliti.com/media/publications/11413 9-ID-pendekatan-sistem-dalam-pengembangansek.pdf

[4] Arifin, M., \& Barnawi. (2014). Kinerja Guru Profesional. Yogyakarta: Ar-Ruzz Media.

[5] Yuniarti, D., \& Lingga. (2019). Pengaruh Pelatihan dan Pengembangan Sumber Daya Manusia dalam Meningkatkan Kinerja Guru Pada SMK Negeri 1 Muntok. Jurnal Efektor, Vol. 6, no. 1, pp. 98-106, https://ojs.unpkediri.ac.id/index.php/efektore/article/view/12794

[6] Candra, V. P., Silaban., \& Sudirman, A. (2019). Pengaruh Gaya Kepemimpinan, Budaya Sekolah dan Motivasi terhadap Kinerja Guru SMP Swasta. Harmoni Sosial: Jurnal Pendidikan IPS, Vol. 6, no. 1, pp. 49-60. https://journal.uny.ac.id/index.php /hsjpi/article/view/25359

[7] Azis, A. Q. (2019). Pengaruh Gaya Kepemimpinan Kepala Sekolah Terhadap Kinerja Guru di SMK Negeri 11 Bandung. Manper: Jurnal Pendidikan Manajemen Perkantoran. Vol. 4, no. 2, pp. 246253. https://ejournal.upi.edu/index.php/jpmanper/ article/view/18020

[8] Yukl G. (2015). Kepemimpinan Dalam Organisasi (7th ed.). Jakarta: PT. Indeks.

[9] Gala, I. N., Ramadhan, H. A. \& Rede A. (2017). Pengaruh Pelatihan dan Motivasi Kerja Terhadap Kinerja Mengajar Guru IPA Di SMP Se-Kota Poso. e-Jurnal Mitra Sains, Volume 5 Nomor 2, April 2017 hlm 58-66. https://www.neliti.com/id/ publications/ 153678/pengaruh-pelatihan-danmotivasi-kerja-terhadap-kinerja-mengajar-guruipa-di-smp

[10] Mulyasa, E. (2014). Guru dalam Implementasi Kurikulum. Bandung: PT Remaja Rosdakarya Offset.

[11] Djafar, H. \& N. N. (2018). Pengaruh Motivasi Kepala Sekolah terhadap Kinerja Guru Dan Pegawai di SMK Muhammadiyah 3 Makassar. Jurnal. Idaarah, vol. 2, no. 1, pp. 24-36. http://journal.uinalauddin.ac.id/index.php/idaarah/article/view/5064

[12] Sari, A. (2014). Pengaruh Motivasi Kerja, Kepemimpinan, dan Budaya Organisasi Terhadap Kinerja Guru SMK Negeri Di Kabupaten Karimun. Universitas Terbuka. http://repository. ut.ac.id/440/

[13] Markonah, S. \& Sunarto. (2016). Pengaruh Motivasi dan Kompetensi Terhadap Kinerja Guru Dimediasi Komitmen Organisasional (Studi Kasus Di SMA Negeri 1 Jakenan Kabupaten Pati). J. Neliti, pp. 1-20. https://www.neliti.com/id/publications/192754/ pengaruh-motivasi-dan-kompetensi-terhadapkinerja-guru-dimediasi-komitmen-organi

[14] Mangkunegara A. A. A. P. (2015). Manajemen Sumber Daya Manusia Instansi/Organisasi. Bandung: Remaja Rosdakarya

[15] Hasibuan, M. S. P. (2016). Manajemen Sumber Daya Manusia. Jakarta: PT. Bumi Aksara,

[16] Atisama, Z. (2017). Pengaruh Pelatihan Dan Disiplin Terhadap Kinerja Guru Sekolah Menengah Pertama Di Lingkungan Unit Pelaksana Teknis Dinas (UPTD) Pendidikan Kecamatan Gunungsitoli Utara. Universitas Terbuka Jakarta. http://repository.ut.ac.id/6784/

[17] Jahangir, S. F., N. Saheen, \& S. F. Kazmi. (2012). In Service Training: A Contributory Factor Influencing Teachers' Performance. nternational Journal of Academic Research in Progressive Education and Development, Vol. 1, No. 1. www.hrmars.com/journals

[18] Baihaqi, M. I. (2015). Pengaruh Gaya Kepemimpinan Kepala Sekolah dan Motivasi Kerja Terhadap Kinerja Guru di MA Ma'arif Selorejo Blitar. Konstruktivisme: Jurnal Pendidikan dan Pembelajaran. Vol. 7, no. 2, pp. 97-106. https://ejournal.unisbablitar.ac.id/index.php/konstr uktivisme/article/view/14

[19] Firmawati, Yusrizal, \& N. Usman. (2017). Pengaruh Kepemimpinan Kepala Sekolah dan Motivasi Kerja terhadap Kinerja Guru. Jurnal. Magister Administrasi Pendidik. Pascasarjana. Univ. Syiah Kuala, vol. 5, no. 3, pp. 167-171, 2017. http://jurnal.unsyiah.ac.id.

[20] Wardana L. W. (2008). Analisis Pengaruh Motivasi Kerja, Disiplin Kerja, Pendidikan dan Pelatihan terhadap Kinerja Guru Sekolah Dasar Negeri di Kecamatan Gayungan Kota Surabaya. Jurnal Penelit., Vol. 2, no. 1, pp. 19-31.

[21] Handayani, D. (2017). Pengaruh Pendidikan dan Pelatihan, Motivasi, Serta Lingkungan Kerja Terhadap Kinerja Guru Smk Negeri Banyuasin. Jurnal Ilmu Manajemen., vol. 6, no. 2, pp. 140-150. https://jurnal.um-palembang.ac.id/ilmu_ manajemen/article/ view/1583 